\title{
Pelatihan Penyusunan Laporan Keuangan Bagi Pelaku UMKM Di Kelurahan Gandoang
}

\author{
Destiana Utarindasari1, Ayu Purnama2, Alvia Prihatini3 \\ 1,2,3 STEBIS Bina Mandiri Cileungsi, Bogor, Indonesia \\ destiana@binamandiri.ac.id
}

\begin{abstract}
Abstrak: Penulisan laporan keuangan menjadi isu yang harus mendapat perhatian dewasa ini, hal ini harus menjadi poin bagi pelaku UMKM dalam memanfaatkan segala fasilitas yang tersedia guna menambah modal kerja. Salah satu fasilitas menambah modal kerja adalah pengajuan kredit bank akan tetapi kurangnya pengetahuan mengenai laporan keuangan menjadi salah satu kendala terhadap pelaku UMKM, adapun tujuan penelitian ini penulis mencoba memfasilitasi pelatihan Penyusunan Laporan keuangan kepada Pelaku UMKM di Kecamatan Cileungsi Ds. Gandoang Kab. Bogor, penulis berharap dengan pelatihan yang telah dilakukan dapat membantu pelaku UMKM melakukan pencatatan Laporan Keuangan sederhana guna mengetahui pengambilan keputusan terhadap kegiatan UMKM yang sedang digeluti, sehingga pengajuan kredit sebagai salah satu fasilitas menambah modal kerja dan syarat administrasi dapat terpenuhi. Melalui metode deskripsi penjelasan akuntansi dan unsur-unsurnya dalam penyusunan laporan keuangan, penulis juga menggunakan metode FGD (Forum Grup Diskusi) agar penyampaian lebih efektif sehingga pelaku UMKM dapat membuat laporan keuangan sederhana yang kemudian menjadi bahan informasi bagi pemberi modal, investor dan lembaga keuangan seperti bank. Hasil penelitian menunjukkan pelaku UMKM Kecamatan Cileungsi Ds. Gandoang Kab. Bogor mampu dan mau belajar akan pentinganya Penyusunan Laporan Keuangan ini diharapkan kedepannya pelaku UMKM dapat melebarkan sayap bisnisnya untuk sebagai urat ekonomi pendukung pemerintah daerah.
\end{abstract}

Kata Kunci: Laporan Keuangan, Akuntansi, UKM

\begin{abstract}
Writing financial statement is an issues which must gain some attention nowadays, this must be a point for MSME for utilizing all the facilities in order to increase their working capital. One of the facility to increase the working capital is to apply for bank credit but a minimum knowledge about financial statement is one of the obstacle to MSME, the purpose of this study is to facilitate the training for preparing financial statement for MSME in Cileungsi Gandoang District, Bogor, the author hopes that the training which has been carried out are able to help MSME to record their financial statement in order to make a decision for their activities, so that credit applications as one of the facilities to increase working capital and administrative requirements fits. With description of accounting and its elements method to conduct financial statement, the author also use Focus Group Discussion to deliver the message effectively so the MSME is able to conduct their simple financial statement for information for the shareholders, investors and other financial institutions such as bank in the future. The study showed that the MSME actors in Cileungsi Gandoang District, Bogor are able and willing to learn about the importance of preparing financial statements and hoped to expand their business to serve the local governance as their economic support.
\end{abstract}

Keywords: Financial Statement, Accounting, SME

\section{Pendahuluan}

Usaha menengah yaitu usaha ekonomi produktif yang berdiri sendiri, yang dilakukan oleh orang perorangan maupun badan usaha yang bukan merupakan anak perusahaan atau cabang perusahaan yang dimiliki, dikuasai, atau menjadi bagian baik langsung maupun tidak langsung dengan usaha kecil atau usaha besar dengan jumlah kekayaan bersih atau hasil penjualan tahunan sebagaimana diatur dalam Undang-Undang. Bentuk UMKM dapat berupa perusahaan perseorangan, persekutuan, seperti misalnya Firma, CV, maupun perseroan terbatas. UMKM dapat dikategorikan menjadi tiga bagian berdasar jumlah asset dan omzet sebagaimana tercantum dalam Undang-Undang Nomor 20 tahun 2008 tentang UMKM sebagai berikut (Hardono, 2010). Hal ini serupa dengan (Kumala.D :2020) "Semakin baik 
pertumbuhan profitabilitas perusahaan berarti prospek perusahaan di masa depan dengan dinilai semakin baik, artinya nilai perusahaan juga akan dinilai semakin baik di mata investor.

Adapun batasan usaha mikro, kecil dan menengah menurut Undang-undang No.20/2008 adalah:

1. Usaha mikro merupakan Usaha produktif milik orang perorangan dan/atau badan usaha perorangan yang memiliki kekayaan bersih paling banyak Rp 50.000.000,00 (lima puluh juta rupiah) tidak termasuk tanah dan bangunan tempat usaha atau memiliki hasil penjualan tahunan paling banyak Rp 300.000.000,00 (tiga ratus juta rupiah).

2. Usaha kecil merupakan Usaha ekonomi produktif yang berdiri sendiri, yang dilakukan oleh orang perorangan atau badan usaha yang bukan merupakan anak perusahaan atau bukan cabang perusahaan yang dimiliki, dikuasai, atau menjadi bagian baik langsung maupun tidak langsung dari usaha menengah atau usaha besar yang memiliki kekayaan bersih lebih dari Rp 50.000.000,00 (lima puluh juta rupiah) sampai dengan paling banyak Rp 500.000.000,00 (lima ratus juta rupiah) tidak termasuk tanah dan bangunan tempat usaha atau memiliki hasil penjualan tahunan lebih dari Rp 300.000.000,00 (tiga ratus juta rupiah) sampai dengan paling banyak Rp 2.500.000.000,00 (dua milyar lima ratus juta rupiah).

3. Usaha Menengah merupakan usaha ekonomi produk yang berdiri sendiri, yang dilakukan oleh orang perorangan atau badan usaha yang bukan merupakan anak perusahaan atau cabang perusahaan yang dimiliki, dikuasai, atau menjadi bagian baik langsung maupun tidak langsung dengan usaha kecil atau usaha besar yang memiliki kekayaan bersih lebih dari Rp 500.000.000,00 (lima ratus juta rupiah) sampai dengan paling banyak Rp 10.000.000.000,00 (sepuluh milyar rupiah) tidak termasuk tanah dan bangunan tempat usaha atau memiliki hasil penjualan tahunan lebih dari Rp 2.500.000.000,00 (dua milyar lima ratus juta rupiah) 49 | Prospek Implementasi SAK EMKM sampai dengan paling banyak Rp 50.000.000.000,00 (lima puluh milyar rupiah).

Menghadapi perkembangan UKM yang akhir-akhir ini tumbuh sangat pesat tidak lain salah satu faktornya adanya program pemerintah untuk mengembangkan usaha kecil menengah dan ekonomi kreatif. Bentuk pemerintah dalam mendukung UKM ini salah satunya adalah dengan memberikan kredit usaha mikro dengan tingkat bunga yang rendah, program dana desa yang digunakan untuk pengembangan potensi desa, dll. Pemberian kredit ini sangat menunjang UKM karena kebanyakan dari pelaku UKM kesulitan untuk mendirikan atau memperbesar usaha mereka dikarenakan kesulitan modal usaha. Permasalahannya adalah salah satu syarat untuk mendapatkan kredit tersebut adalah UKM tidak memiliki Laporan Keuangan atau catatan atas transaksi yang dilakukan oleh UKM (Mulyani et al., 2019). Hal ini dikarenakan minimnya pengetahuan UKM tentang penyusunan laporan keuangan.

Banyak hal yang harus dipelajari dalam penyusunan laporan keuangan untuk UKM yang dikaitkan dengan ilmu akuntansi. Dalam laporan keuangan berisi tentang Neraca yang isinya 
adalah aset, utang dan modal yang UKM miliki, laporan laba rugi, laporan arus kas. Dari laporan keuangan yang dibuat oleh UKM inilah nantinya bank melihat performa dari UKM tersebut dan memberikan penilaian berapa besar kredit yang bisa diberikan.

Bagi dunia pendidikan, keadaan ini harus dipersiapkan dari awal untuk mempersiapkan mahasiswa dalam menghadapi dunia usaha dengan memberikan aplikasi teori dalam pembuatan laporan keuangan yang lebih real salah satunya adalah kegiatan pemberian pelatihan penyusunan laporan keuangan. Ini menjadi jembatan yang baik dari sisi dunia pendidikan dan juga UKM, karena bisa saling menguntungkan. Bagi mahasiswa dapat mempraktikkan teori yang dipelari secara real, sedangkan bagi UKM diharapkan lebih mudah dalam mencerna inti dari pelatihan yang diberikan.

Kompleksitas dalam pembuatan laporan keuangan tersebut yang biasanya sulit juga dipelajari dalam dunia pendidikan karena hanya berdasarkan soal-soal. Realita saat terjun akan sedikit berbeda karena proses penyusunan laporan keuangan bukan hanya dengan soal tapi tindakan untuk memperoleh data-data untuk mengumpulkannya dan menuangkan dalam laporan keuangan bahkan mampu menganalisa laporan keuangan yang dibuat tersebut.

\section{Metode}

\section{Akuntansi}

Dalam penyusunan laporan keuangan penting pemula memahami pengertian dari akuntansi. Akuntansi ini akan membantu menerjemahkan langkah-langkah dan hal-hal yang berkaitan dengan penyusunan laporan keuangan. Kegiatan Akuntansi adalah kegiatan untuk mengumpulkan bukti transaksi, mencatat, menganalisis, menyajikan dalam bentuk angka serta melaporkan aktivitas/transaksi suatu badan usaha dalam bentuk informasi keuangan.

Dalam metodenya, penulis melakukan pelatihan kepada pelaku UKM dalam:

1. Mengumpulkan bukti transaksi, yakni mengumpulkan seluruh informasi berupa bukti transaksi yang terjadi seperti kuintansi pembelian, penjualan untuk kemudian dicatat kedalam jurnal.

2. Mencatat, berarti membuat jurnal atas bukti transaksi yang telah dikumpulkan oleh pelaku UKM. Penjurnalan dilakukan sesuai tanggal terjadinya transaksi.

3. Melakukan posting ke Buku Besar atas setiap pos pos jurnal untuk satu periode.

4. Membuat neraca saldo dan mengkonfirmasi kembali apakah ada pos/akun yang harus disesuaikan pada akhir periode tertentu, seperti perlengkapan UKM.

5. Menyajikan laporan keuangan kedalam neraca, laba rugi dan perubahan modal pada periode tertentu.

\section{Pengertian Laporan Keuangan}

Laporan Keuangan Munawir (2004) pada dasarnya adalah hasil dari proses akuntansi yang dapat digunakan sebagai alat untuk berkomunikasi antara data keuangan atau aktivitas suatu perusahaan denganpihak yang berkepentingan dengan data atau aktivitas perusahaan tersebut Laporan keuangan (financial statement) merupakan hasil akhir dari proses akuntansi. Laporan ini merupakan ringkasan transaksi selama periode tertentu. 
Dalam PSAK Nomor 1 paragraf 08, disebutkan bahwa Laporan keuangan yang lengkap terdiri dari komponenkomponen berikut ini:

1. Laporan laba rugi komprehensif selama periode (income statement): laporan keuangan yang menunjukkan hasil usaha (penghasilan dan biaya) unit usaha selama periode tertentu.

2. Laporan perubahan Ekuitas / modal (statement of changes owners' equity): laporan keuangan yang menunjukkan perubahan modal unit usaha (modal awal, tambahan dan pengurangan modal, dan modal akhir) selama periode tertentu. Laporan ini lazim digunakan pada usaha yang berbentuk perorangan, firma, dan CV.

3. Laporan laba ditahan (retained earning statement): laporan keuangan yang menunjukkan akumulasi sisa hasil usaha yang belum dibagikan kepada dividen selama periode tertentu.

4. Laporan perubahan posisi keuangan akhir periode (statement changes of financial statement): laporan keuangan yang menunjukkan perbandingan aktiva, utang, dan modal pada dua saat tertentu.

5. Laporan arus kas (cash flow statement): laporan keuangan yang menunjukkan perubahan kas dan setara kas selama periode tertentu.

6. Catatan atas laporan keuangan (notes to financial statement): catatan penting yang mendasari pengukuran, pengakuan, metode pencatatan atas akun-akun pada laporan keuangan, misalnya kebijaksanaan akuntansi.

7. laporan posisi keuangan pada awal periode komparatif yang disajikan ketika entitas menerapkan suatu kebijakan akuntansi secara retrospektif atau membuat penyajian kembali pos-pos laporan keuangan, atau ketika entitas mereklasifikasi pos-pos dalam laporan keuangannya.

\section{Siklus Akuntansi}

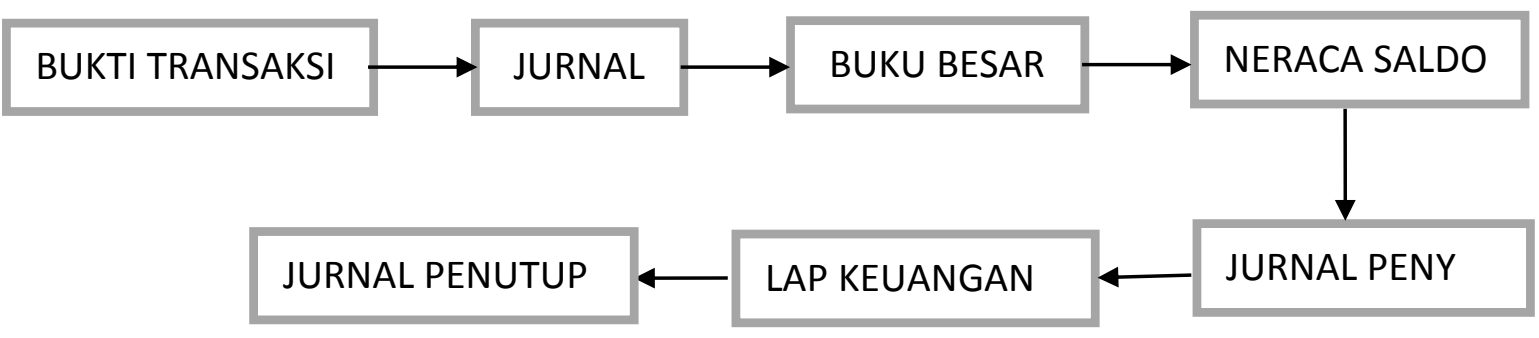

Bagan 1. Siklus Akuntansi

\section{Penyusunan Laporan Keuangan Berdasarkan SAK Entitas Mikro Kecil dan Menengah}


Cara penyajian laporan keuangan UKM telah disusun secara rinci pada SAK EMKM yang penyajiannya harus konsisten dan lengkap. Laporan keuangan tersebut minimal terdiri dari:

1. Laporan posisi keuangan pada akhir periode (neraca),

2. Laporan laba rugi selama periode (laporan laba/rugi),

3. Catatan atas laporan keuangan, yang berisi tambahan dan rincian pos-pos tertentu yang relevan.

a. Laporan Posisi Keuangan Pada Akhir Periode

Unsur - unsur posisi keuangan pada akhir periode adalah sebagai berikut:

1) Aset, adalah sumber daya yang dikuasai oleh entitas sebagai akibat dari peristiwa masa lalu dan yang dari mana manfaat ekonomik di masa depan diharapkan akan diperoleh oleh entitas.

2) Liabilitas, adalah kewajiban kini entitas yang timbul dari peristiwa masa lalu, yang penyelesaiannya mengakibatkan arus keluar dari sumber daya entitas yang mengandung manfaat ekonomik.

3) Ekuitas, adalah hak residual atas aset entitas dikurangi seluruh liabilitasnya.

Informasi yang disajikan dalam Laporan posisi keuangan entitas mencakup pos-pos berikut:

1) Kas dan Setara Kas

2) Piutang

3) Persediaan

4) Aset tetap

5) Utang Usaha

6) Utang Bank

7) Ekuitas

Tabel 1. Laporan Posisi Keuangan / Neraca

\section{ENTITAS}

\section{LAPORAN POSISI KEUANGAN 31 DESEMBER $20 \times 8$}

\begin{tabular}{|c|c|}
\hline$\overline{\text { ASET }}$ & $20 \times 7$ \\
\hline Kas & $x x x$ \\
\hline Giro dan Cek & $x x x$ \\
\hline Deposito & $x x x$ \\
\hline Jumlah kas dan setara kas & $\mathbf{x x x}$ \\
\hline Piutang usaha & $x x x$ \\
\hline Persediaan & $x x x$ \\
\hline Beban dibayar di muka & $x x x$ \\
\hline Aset tetap & $x x x$ \\
\hline Akumulasi penyusutan & $(\mathrm{xx})$ \\
\hline JUMLAH ASET & $x \boldsymbol{x} x$ \\
\hline \multicolumn{2}{|l|}{ LIABILITAS } \\
\hline Utang usaha & $x x x$ \\
\hline Utang bank & $x x x$ \\
\hline JUMLAH LIABITITAS & $x x x$ \\
\hline
\end{tabular}




\begin{tabular}{ll}
\hline EKUITAS & \\
Modal & $\mathrm{xxx}$ \\
Saldo laba (defisit) & $\mathrm{xxx}$ \\
\hline JUMLAH EKUITAS & $\boldsymbol{X X X}$ \\
\hline JUMLAH LIABILITAS \& EKUITAS & $\boldsymbol{x} \boldsymbol{X X}$ \\
\hline
\end{tabular}

Sumber : SAK EMKM (2018)

b. Laporan Laba Rugi Selama Periode

Informasi kinerja keuangan entitas terdiri dari informasi mengenai penghasilan dan beban selama periode pelaporan, dan disajikan dalam laporan laba-rugi. Unsur-unsur tersebut didefinisikan sebagai berikut:

1) Penghasilan (income), adalah kenaikan manfaat ekonomik selama periode pelaporan dalam bentuk arus kas masuk atau kenaikan aset, atau penurunan liabititas yang mengakibatkan kenaikan ekuitas yang tidak berasal dari kontribusi penanaman modal.

2) Beban (expense), adalah penurunan manfaat ekonomik selama periode pelaporan dalam bentuk arus kas keluar atau penurunan aset, atau kenaikan liabilitas yang mengakibatkan penurunan ekuitas yang tidak disebabkan oleh distribusi kepada penanam modal.

Informasi yang disajikan dalam laporan laba rugi entitas dapat mencakup pos-pos sebagai berikut:

1) Pendapatan

2) Beban Keuangan

3) Beban Pajak

Tabel 2. Laporan Laba Rugi

\begin{tabular}{|c|c|c|}
\hline $\begin{array}{l}\text { ENTITAS } \\
\text { LAPORAN LABA RUGI } \\
\text { UNTUK TAHUN YANG BERAKHIR }\end{array}$ & 31 DESEMBER $20 \times 8$ & \\
\hline PENDAPATAN & & $20 \times 7$ \\
\hline Pendapatan usaha & & $x x x$ \\
\hline Pendapatan lain - lain & & $x x x$ \\
\hline JUMLAH PENDAPATAN & & $\mathbf{x x x}$ \\
\hline \multicolumn{3}{|l|}{ BEBAN } \\
\hline Beban usaha & & $x x x$ \\
\hline Beban lain - lain & & $x x x$ \\
\hline JUMLAH BEBAN & & $\mathbf{X X X}$ \\
\hline LABA(RUGI) SEBELUM PAJAK & & \\
\hline \multicolumn{3}{|l|}{ PENGHASILAN } \\
\hline Beban pajak penghasilan & & $x x x$ \\
\hline \multicolumn{3}{|l|}{ LABA(RUGI) SETELAH PAJAK } \\
\hline PENGHASILAN & & \\
\hline
\end{tabular}

Sumber : SAK EMKM (2018)

c. Catatan Atas Laporan Keuangan, yang berisi tambahan dan rincian pos-pos tertentu 
yang relevan, catatan laporan keuangan memuat:

1) Suatu pernyataan bahwa laporan keuangan telah disusun sesuai SAK EMKM.

2) Ikhtisar kebijakan akuntansi.

3) Informasi tambahan rincian pos tertentu yang menjelaskan transaksi penting dan material sehingga bermanfaat bagi pengguna untuk memahami laporan keuangan.

Table 3. Catatan Atas Laporan Keuangan

\section{ENTITAS}

CATATAN ATAS LAPORAN KEUANGAN

31 DESEMBER 20XX

\section{UMUM}

Entitas didirikan di Kab Bogor Gandoang berdasarkan Surat Ijin Usaha/Akta (Bulan) 20xx yang dibuat dihadapan Notaris, S.H., notaris di Bogor dan mendapatkan persetujuan dari Menteri Hukum dan Hak Asasi Manusia No.xx 20xx tanggal (Tgl/Bln/Thn.) Entitas bergerak dalam bidang usaha manufaktur. Entitas memenuhi kriteria sebagai entitas mikro, kecil, dan menengah sesuai UU Nomor 20 Tahun 2008. Entitas berdomisili di jalan xxx, Bogor.

\section{IKHTISAR KEBIJAKAN AKUNTANSI PENTING}

\section{a. Pernyataan Kepatuhan}

Laporan keuangan disusun menggunakan Standar Akuntansi Keuangan Entitas Mikro, Kecil, dan Menengah.

\section{b. Dasar Penyusunan}

Dasar penyusunan laporan keuangan adalah biaya historis dan menggunakan asumsi dasar akrual

\section{c. Piutang Usaha}

Piutang usaha disajikan sebesar jumlah tagihan.

\section{d. Persediaan}

Biaya persediaan bahan baku meliputi biaya pembelian dan biaya angkut pembelian. Biaya konversi meliputi biaya tenaga kerja langsung dan overhead. Overhead tetap dialokasikan ke biaya konversi berdasarkan kapasitas produksi normal.

\section{e. Aset Tetap}

Aset tetap dicatat sebesar biaya perolehannya jika aset tersebut dimiliki secara hukum oleh entitas. Aset tetap disusutkan menggunakan metode garis lurus tanpa nilai residu.

\section{f. Pengakuan Pendapatan dan Beban}

Pendapatan penjualan diakui ketika tagihan diterbitkan atau pengiriman dilakukan kepada pelanggan. Beban diakui saat terjadi.

\section{g. Pajak Penghasilan}

Pajak penghasilan mengikuti ketentuan perpajakan yang berlaku di Indonesia.

3. KAS

Kas kecil

20XX

4. GIRO

Bank

5. DEPOSIT

PT. Bank xxx - Rupiah

Suku bunga - Rupiah

6. PIUTANG USAHA

Toko A

Toko B

Jumlah

7. BEBAN DI BAYAR DI MUKA

Sewa

Asuransi

Jumlah 20xx

$x x x$

$x x x$

$x x x$

$20 x x$

$x x x$

$x x x$

$\mathbf{x x x}$ 


\section{UTANG BANK}

Pada tanggal x, Bulan X, 20xx, Entitas memperoleh pinjaman Kredit Modal Kerja (KMK) dari PT Bank $A B C$ dengan maksimum kredit Rpxxx, suku bunga efektif $x x \%$ per tahun dengan jatuh tempo berakhir tanggal xx BulanX 20xx. Pinjaman dijamin dengan persediaan dan sebidang tanah milik entitas.

\section{SALDO LABA}

Saldo laba merupakan akumulasi selisih penghasilan dan beban, setelah dikurangkan dengan distribusi kepada pemilik.

\section{PENDAPATAN PENJUALAN}

Penjualan

Retur penjualan

$20 x x$

Jumlah

\section{Hasil dan Pembahasan}

Secara geografis, Desa Gandoang terletak di Kabupaten Bogor Kecamatan Cileungsi dengan luas $640 \mathrm{Ha}$. Desa Gandoang merupakan suatu wilayah yang tumbuh, dengan banyak perumahan, ada perumahan karyawan pabrik, ada perumahan campuran dan perumahan khusus untuk militer. Karena banyaknya kawasan industri yang dibangun di wilayah ini, berkembang pula banyak UKM yang diselenggarakan sendiri oleh penduduk setempat.

Pelaksanaan kegiatan PKM ini secara umum sesuai dengan target tim pengabdian, mulai dari jumlah peserta, hasil yang diharapkan, dan evaluasi yang berjalan dengan lancar, walaupun ada berbagai hambatan mulai dari mencari waktu yang tepat sampai masalah pencarian tempat, akhirnya semua bisa dipecahkan dengan kerjasama semua pihak yang mendukung terselenggaranya kegiatan ini.

Jumlah peserta yang mengikuti kegiatan ini sangat banyak. Peserta yang mengikuti kegiatan ini tidak hanya berasal dari anggota koperasi, tetapi ada juga anak-anak muda diluar koperasi sehingga peneliti membentuk Forum Diskusi Grup (FGD) untuk mempermudah penjelasan materi yang disampaikan.

Pelaksanaan kegiatan Pengabdian ini dilaksanakan selama satu hari, dipadatkan dari jadwal semula yang direncanakan selama 2 hari tetapi materi yang disampaikan sekaligus jam tatap muka tetap sesuai dengan rencana. Hal ini perlu dilakukan mengingat keterbatasan waktu yang dimiliki oleh peserta, sehingga pada akhirnya tim pengabdi bersepakat dengan peserta untuk melaksanakan kegiatan selama satu hari tetapi dengan jumlah jam yang panjang.

Pelaksanaan kegiatan pengabdian pada masyarakat yang telah dilaksanakan oleh tim pengabdi telah mendapatkan respon yang positif dari peserta. Sejak pertama kali program ini dibicarakan dengan perkumpulan Para Peserta Didik, antusiasme sangat terasa, koordinasi telah dilakukan secara terus menerus untuk mendapatkan waktu yang pas kapan pelaksanaan kegiatan ini akan dimulai. Kesulitan yang timbul dalam pelaksanaan PKM ini tidak lain adalah 
menyinkronkan antara jadwal para peserta dengan jadwal tim pengabdi. Setelah melakukan koordinasi berualang kali akhirnya disepakati.

Dari beberapa kesan dan masukan dari peserta, umumnya mereka merasa sangat antusias dalam mengikuti kegiatan ini, metode yang digunakan dalam pelatihan ini tidak memforsir mereka untuk langsung bisa menguasai materi pelatihan, tetapi sedikit demi sedikit asalkan yang penting paham, sehingga di awal terkesan waktu yang digunakan untuk pemahaman relatif lama. Akan tetapi ternyata waktu untuk memahami yang relatif lama inilah yang menjadi keunggulan pelatihan ini, karena hampir semua peserta menjadi benar-benar paham.

Hasil dari pelatihan ini melebihi ekspektasi dari tim pengabdi, dikarenakan antusiasme peserta yang begitu besar. Walaupun mungkin dari segi isi dan materi mungkin masih banyak kekurangan, tetapi pada dasarnya peserta sudah mampu memahami inti dan tujuan dari pelatihan ini.

Pada intinya pelaksanaan Pengabdian dapat berjalan dengan baik dan lancar, follow up dari kegiatan ini nantinya diharapkan peserta pelatihan untuk terus mencoba dan sebisa mungkin menerapkannya dalam kegiatan perkumpulan untuk keberlanjutan Pengetahuan.

\section{Kesimpulan}

Berdasarkan survey penelitian terhadap para peserta, peneliti dapat melihat bahwa Pelaku UKM belum sepenuhnya dapat menyusun laporan keuangan akan tetapi melalui pelatihan pelaku UKM dapat menyusun laporan keuangan sederhana berupa arus kas hanya untuk mengetahui keuntungan yang diperoleh melalui penjualan pada periode yang telah ditentukan. Diharapkan melalui pelatihan ini Pelaku UKM dapat lebih mengerti akan pentingnya melakukan pencatatan keuangan atas transaksi keuangan dan kegiatan UKM yang dilakukannya sehingga pelaku UKM dapat mengembangkan bisnis dengan pengajuan modal kerja dimana Laporan Keuangan sebagai salah satu syarat administrasi yang harus dipenuhi.

\section{Referensi}

Mulyani, A. S., Nurhayaty, E., \& Miharja, K. (2019). Penerapan Pencatatan dan Laporan Akuntansi Pada Usaha Mikro Kecil Dan Menengah (UMKM). Jurnal Abdimas BSI: Jurnal Pengabdian Kepada Masyarakat, 2(2), 219-226. https://doi.org/10.31294/jabdimas.v2i2.5818

Rudianto. (2012). Konsep dan Teknik Penyusunan laporan keuangan, Jakarta: Erlangga.

Zimmerer, T. W., \& Scarborough, N. M. (2008). Kewirausahaan dan Manajemen Usaha Kecil. Salemba Empat.

Kumala, D. (2020). Pengaruh Profitabilitas Terhadap Return Saham Dengan Nilai Perusahaan Sebagai Variabel Mediasi Pada Indeks Saham Syariah Indonesia Sektor Industri Barang Konsumsi Periode 2013-2017. I-Finance: A Research Journal on Islamic Finance, 6(2), 90-105. https://doi.org/https://doi.org/10.19109/ifinance.v6i2.7040

Hasan, Amir \& Gusnardi. (2018). PROSPEK IMPLEMENTASI STANDAR AKUNTANSI : Entitas Mikro, Kecil dan Menengah Berbasis Kualitas Laporan Keuangan Yang Berlaku Efektif Per 1 Januari 2018. Bandung: The Sadari Institute (SADARIPRESS) 